\title{
The Influence of Intellectual Capital on the Company's Financial Performance and Market Value
}

\author{
Anindya Ardiansari ${ }^{1, *}$, Siti Ridloah ${ }^{1}$, Irene Rini Demi Pangestuti ${ }^{2}$, Pipit Indriyani ${ }^{1}$ \\ ${ }^{1}$ Management Department, Faculty of Economics, Universitas Negeri Semarang, Semarang, Indonesia \\ ${ }^{2}$ Management Department, Faculty of Economics and Business, Diponegoro University, Semarang, Indonesia
}

Received February 2, 2021; Revised March 23, 2021; Accepted April 18, 2021

\section{Cite This Paper in the following Citation Styles}

(a): [1] Anindya Ardiansari, Siti Ridloah, Irene Rini Demi Pangestuti, Pipit Indriyani , "The Influence of Intellectual Capital on the Company's Financial Performance and Market Value," Universal Journal of Accounting and Finance, Vol. 9, No. 2, pp. 217 - 225 , 2021. DOI: 10.13189/ujaf.2021.090211.

(b): Anindya Ardiansari, Siti Ridloah, Irene Rini Demi Pangestuti, Pipit Indriyani (2021). The Influence of Intellectual Capital on the Company's Financial Performance and Market Value. Universal Journal of Accounting and Finance, 9(2), 217 - 225. DOI: 10.13189/ujaf.2021.090211.

Copyright@2021 by authors, all rights reserved. Authors agree that this article remains permanently open access under the terms of the Creative Commons Attribution License 4.0 International License

\begin{abstract}
The development of property and real estate companies in Indonesia is expanding. Property and real estate companies have great opportunities to further develop their companies. However, an increase in intellectual capital investment does not affect financial performance and market value. Therefore, this study aims to examine the effect of intellectual capital on financial performance and the market value of the property and real estate companies in Indonesia from 2014 to 2018. The population of this research is 56 property and real estate companies listed on the Indonesia Stock Exchange (IDX) from 2014 to 2018, then the sampling technique used is purposive sampling which results in 42 companies being studied with 210 observations. This study uses independent variables, namely Value Added Capital Employed, Value Added Human Capital, and Structural Capital Value Added as a representation of intellectual capital. The dependent variables in this study are financial performance and market value. The data analysis technique used is multiple linear regression. The results show that simultaneously intellectual capital has an effect on financial performance, but it has no significant effect on market value. Partially, only structural capital has a positive and significant effect on the company's financial performance. This study has limitations, namely, the results show that the level of influence of intellectual capital on financial performance and market value is low. Therefore, it is suggested that further research should include other variables such as corporate social responsibility and good corporate
\end{abstract}

governance.

Keywords Intellectual Capital, Financial Performance, Market Value

\section{Introduction}

In the era of globalization which is increasingly advanced with the increasing use of technology, companies need to create the right strategy. The company changed its strategy from a labor-based business to a knowledge-based business. According to [1] resources are seen as valuable assets because they are considered to be the main factors that determine the success of a company. Maximum management of knowledge resources will affect investors' views on the company, thereby affecting the overall market value. This will also have an impact on financial performance [2].

Financial performance shows everything that the workforce does to generate profits [3]. As a reference for investors and management, financial performance is used for decision-making. The company's financial performance is a factor considered by investors in investing [4]. Good financial performance will attract investors to invest. Financial statements are used as a measurement of financial performance. Financial statements contain a variety of important information including market share, 
business information, company prospectus, and others [5].

However, financial statements cannot guarantee to show financial performance accurately. Therefore, an analysis tool is needed, namely financial ratios to measure it [6]. Several financial ratios have been put forward by experts, but this study uses a profitability ratio, namely return on equity (ROE) [5].

Market value rests on the overall value of shares issued by a company at a certain time based on market mechanisms [7]. When the market views the company as exceeding the value of invested capital, it means that management has created value for stakeholders [8]. The better market view of the company will make it easier to collect funds so that the company's operations will run well and of course can improve financial performance [9]. The higher share value means that the owner's welfare will increase [10]. Measurement of market value uses the market to book value (MtBV) [11].

Every effort is made by the company to increase profits by utilizing its resources to create value as a reflection of the company's success. According to [12], it will have a big influence when intellectual capital as an intangible resource is managed effectively and efficiently.

PSAK No. 19 (revised 2000) intellectual capital is an identifiable intangible asset that is not in physical form which is used to produce goods/services. In general, researchers state that intellectual capital consists of three main components, namely relational capital, human capital, and structural capital [13]. The examples of relational capital are brands, customer loyalty, and company names. The examples of human capital are know-how, education, and work-related knowledge. Structural capital includes copyrights, infrastructure assets, and information systems. Every component of intellectual capital is very important [14] because it is used to create added value for the company.

Company profits are obtained from the added value that the company creates for its owners [15]. The higher the value-added, the greater the investor's interest in the company. Value-added is obtained from intangible income [16]. According to [17] measuring intellectual capital uses the Value Added Intellectual Coefficient - VAICTM. Measurements used include Value Added Capital Employed (VACA), Value Added Human Capital (VAHU), and Structural Capital Value Added (STVA).

The development of property and real estate companies in Indonesia is expanding. Property and real estate companies have great opportunities to further develop their companies. Based on the Resourced-Based Theory, accurate resource management can create a competitive advantage for the company [18]. This is important because the competitive advantage is at the heart of company performance [15]. When the company has maximized intellectual capital, it should have an impact on improving financial performance which in turn will increase market value. However, the facts in the field show a different phenomenon. There is an inconsistency between theory and facts in the field. This can be seen in table 1 .

Table 1. Intellectual Capital, Financial Performance and Market Value

\begin{tabular}{|c|c|c|c|c|c|}
\hline & 2014 & 2015 & 2016 & 2017 & 2018 \\
\hline VACA & 0.2427 & 0.2350 & 0.3117 & 0.3094 & 0.1853 \\
\hline ROE & 0.1063 & 0.0762 & 0.0768 & 0.0600 & 0.0538 \\
\hline MtBV & 94.259 & 70.284 & 61.109 & 63.543 & 62.918 \\
\hline
\end{tabular}

Source: Indonesia Stock Exchange (2020)

Table 1 shows that the value-added generated from VACA has increased in 2016, but the value of ROE and MtBV decreased in that year. This means that intellectual capital has increased, but the financial performance and market value have actually decreased. So, it can be concluded that there is an inconsistency in the relationship between the VACA variable and ROE and MtBV.

In addition, there is also a research gap from several previous studies related to the relationship between intellectual capital and company performance and market value. This can be seen in Table 2 below. 
Table 2. Summary of Research Gap from Previous Research Results

\begin{tabular}{|c|c|c|}
\hline Variable & References & Result \\
\hline \multirow[t]{4}{*}{$\begin{array}{l}\text { Capital Emlpoyed/VACA (X) } \\
\text { Financial performance }(\mathrm{Y}) \\
\end{array}$} & $\begin{array}{l}{[19]} \\
{[20]}\end{array}$ & VACA has a positive and significant effect on financial performance \\
\hline & $\begin{array}{l}{[21]} \\
{[22]}\end{array}$ & VACA has a positive and insignificant effect on financial performance \\
\hline & $\begin{array}{l}{[23]} \\
{[24]}\end{array}$ & VACA has a negative and significant effect on financial performance \\
\hline & $\begin{array}{l}{[25]} \\
{[26]}\end{array}$ & VACA has a negative and insignificant effect on financial performance \\
\hline \multirow[t]{4}{*}{$\begin{array}{l}\text { Human Capital/VAHU }(\mathrm{X}) \\
\text { Financial performance }(\mathrm{Y}) \\
\end{array}$} & $\begin{array}{l}{[27]} \\
{[28]}\end{array}$ & VAHU has a positive and significant effect on financial performance \\
\hline & $\begin{array}{l}{[24]} \\
{[22]}\end{array}$ & VAHU has a positive and insignificant effect on financial performance \\
\hline & $\begin{array}{l}29] \\
{[30]}\end{array}$ & VAHU has a negative and significant effect on financial performance \\
\hline & $\begin{array}{l}{[31]} \\
{[32]}\end{array}$ & VAHU has a negative and insignificant effect on financial performance \\
\hline \multirow[t]{4}{*}{$\begin{array}{l}\text { Structural Capital/STVA (X) } \\
\text { Financial performance (Y) }\end{array}$} & $\begin{array}{l}{[33]} \\
{[19]}\end{array}$ & STVA has a positive and significant effect on financial performance \\
\hline & $\begin{array}{l}{[21]} \\
{[34]}\end{array}$ & STVA has a positive and insignificant effect on financial performance \\
\hline & [32] & STVA has a negative and significant effect on financial performance \\
\hline & $\begin{array}{l}{[27]} \\
{[35]}\end{array}$ & STVA has a negative and insignificant effect on financial performance \\
\hline \multirow[t]{4}{*}{$\begin{array}{c}\text { Capital Emlpoyed/VACA (X) } \\
\text { Market value (Y) } \\
\end{array}$} & $\begin{array}{l}33] \\
{[36]}\end{array}$ & VACA has a positive and significant effect on Market Value \\
\hline & $\begin{array}{l}{[23]} \\
{[21]}\end{array}$ & VACA has a positive and insignificant effect on Market Value \\
\hline & [37] & VACA has a negative and significant effect on Market Value \\
\hline & $\begin{array}{l}{[26]} \\
{[38]}\end{array}$ & VACA has a negative and insignificant effect on Market Value \\
\hline \multirow[t]{4}{*}{$\begin{array}{l}\text { Human Capital/VAHU (X) } \\
\text { Market value (Y) }\end{array}$} & $\begin{array}{l}{[21]} \\
{[20]}\end{array}$ & VAHU has a positive and significant effect on Market Value \\
\hline & $\begin{array}{l}{[23]} \\
{[27]}\end{array}$ & VAHU has a positive and insignificant effect on Market Value \\
\hline & $\begin{array}{l}{[31]} \\
{[38]}\end{array}$ & VAHU has a negative and significant effect on Market Value \\
\hline & $\begin{array}{l}{[33]} \\
{[24]}\end{array}$ & VAHU has a negative and insignificant effect on Market Value \\
\hline \multirow[t]{4}{*}{$\begin{array}{c}\text { Structural Capital/STVA (X) } \\
\text { Market value (Y) }\end{array}$} & $\begin{array}{l}{[27]} \\
{[35]}\end{array}$ & STVA has a significant positive effect on Market Value \\
\hline & $\begin{array}{l}{[25]} \\
{[20]}\end{array}$ & STVA has a positive and insignificant effect on Market Value \\
\hline & $\begin{array}{l}32] \\
{[30]}\end{array}$ & STVA has a negative and significant effect on Market Value \\
\hline & $\begin{array}{l}{[21]} \\
{[26]}\end{array}$ & STVA has a negative and insignificant effect on Market Value \\
\hline
\end{tabular}

Source: Research articles reprocessed (2020)

From the explanation above, the objective of this study is to analyze the effect of intellectual capital on the company's financial performance and market value. This research will be tested on property and real estate companies listed on the Indonesia Stock Exchange from 2014 to 2018. Researchers take this sector company because there is still a lack of empirical evidence on property sector companies. The variables used in this study consist of the dependent variable, namely intellectual capital (VAIC), and the independent variable, namely financial performance (ROE) and market value (MtBV).

\subsection{Hypothesis Development}

VACA shows how much the company's ability to manage its physical capital [17]. A combination of capital owned by the company, coupled with proper management, will improve financial performance. In accordance with [32] and [28] that VACA has a significant positive effect on financial performance, the hypothesis is compiled as follows:

H1: Capital Employed (VACA) has a significant positive effect on Company Financial Performance (ROE) 
VAHU is the ability to generate company value from the funds spent on labor [17]. The better managing these funds, the better financial performance will be. In accordance with [33] and [28] that VAHU has a significant positive effect on financial performance, the hypothesis is compiled as follows:

H2: Human Capital (VAHU) has a significant positive effect on Company Financial Performance (ROE)

STVA is the company's ability to support employees' efforts to generate optimal value [17]. In line with [33] and [19] that STVA has a significant positive effect on financial performance, the hypothesis is compiled as follows:

H3: Structural Capital (STVA) has a significant positive effect on Company Financial Performance (ROE)

The effective and efficient use of VACA will increase the company's revenue and will be followed by an increase in market value. According to [32] and [36] that VACA has a significant positive effect on market value, the hypothesis is compiled as follows:

H4: Capital Employed (VACA) has a significant positive effect on the Company's Market Value (MtBV)

VAHU as a source of innovation and strategy that forms positive market perceptions is the company's ability to equip its employees with expertise. The better the management, the more positive the impact on market value. In accordance with [21] and [32] state that VAHU has a positive and significant effect on market value, the hypothesis is compiled as follows:

H5: Human Capital (VAHU) has a significant positive effect on Company Market Value (MtBV)

STVA is the ability to create value-added to increase sales, thereby increasing market value. In line with [27] and [35] that STVA has a positive and significant effect on market value, the hypothesis is compiled as follows:

H6: Structural Capital (STVA) has a significant positive effect on Firm Market Value (MtBV).

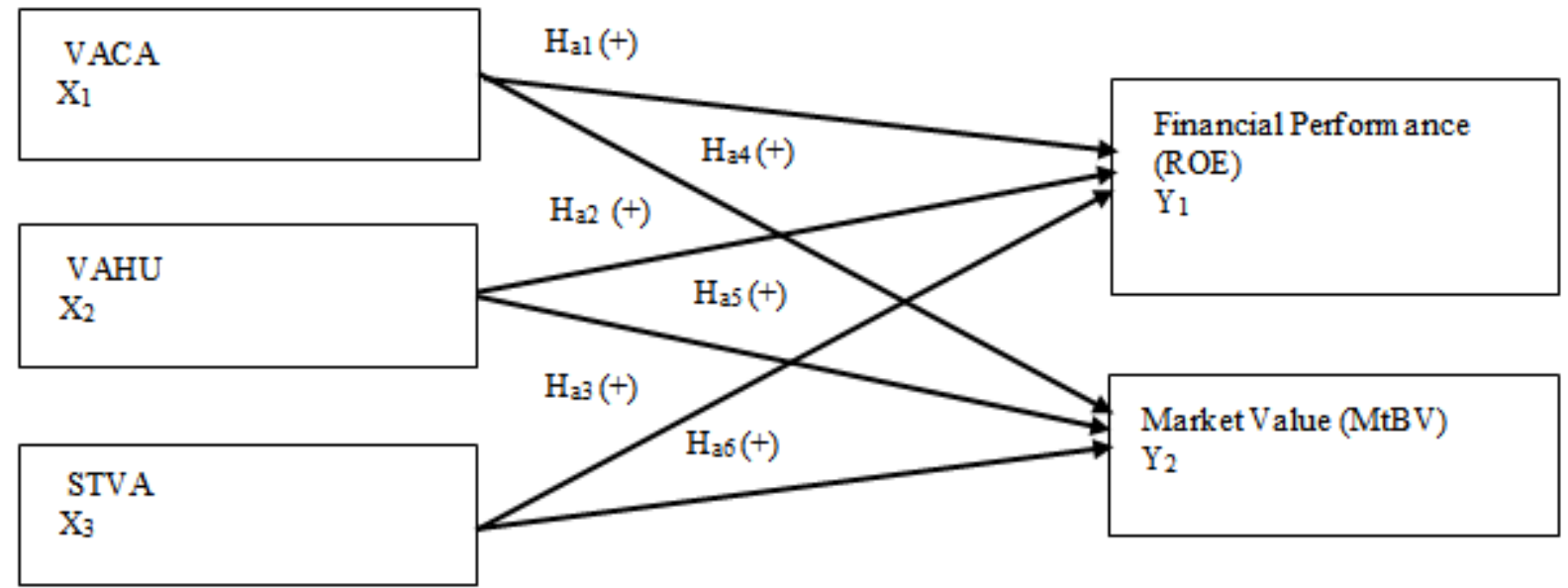

Figure 1. Research Model

Table 3. Measurement of Research Variables

\begin{tabular}{|c|c|c|c|c|}
\hline Variable & Definition & Measurement & Scale & Reference \\
\hline $\begin{array}{l}\text { Value Added Capital } \\
\text { Employed (VACA) }\end{array}$ & $\begin{array}{l}\text { Describes how much value-added is } \\
\text { generated from the physical capital used. }\end{array}$ & Value-added/equity & Ratio & [16] \\
\hline $\begin{array}{l}\text { Value Added Human } \\
\text { Capital (VAHU) }\end{array}$ & $\begin{array}{l}\text { The ability of the workforce to generate } \\
\text { value for the company from the funds spent } \\
\text { on labor }\end{array}$ & $\begin{array}{l}\text { Value- added/employee } \\
\text { expenses }\end{array}$ & Ratio & [16] \\
\hline $\begin{array}{l}\text { Structural Capital Value } \\
\text { Added (STVA) }\end{array}$ & $\begin{array}{l}\text { The ability to meet all company needs to } \\
\text { generate value for the company comes from } \\
\text { good management of systems and } \\
\text { processes, as well as company culture }\end{array}$ & $\begin{array}{l}\text { The difference in value-added } \\
\text { and employee expenses/Value } \\
\text { added }\end{array}$ & Ratio & [16] \\
\hline Financial Performance & $\begin{array}{l}\text { measure the success of a company in } \\
\text { generating profits }\end{array}$ & net profit/Equity & Ratio & [5] \\
\hline Market Value & asset prices referenced from the market & Market value/book value & Ratio & [27] \\
\hline
\end{tabular}

Source: processed data (2020) 


\section{Methodology}

The object of this study is a complete annual financial statement that has passed the audit on property and real estate companies listed on the IDX for the 2014-2018 period. This type of research data uses quantitative data. The population of this research is property and real estate companies. Sampling using a purposive sampling technique, where the sample is determined based on certain criteria. The companies selected as samples in this study are companies that meet the following criteria: 1) Companies listed on the Indonesia Stock Exchange (IDX) consecutively during the 2014-2018 period. 2) Companies with complete and audited financial reports for the 2014-2018 period. Based on these criteria, there were 42 companies as the research sample with 210 observations.

This study uses independent variables, namely Value Added Capital Employed (VACA), Value Added Human Capital (VAHU), and Structural Capital Value Added (STVA). And the dependent variable is financial performance and market value. The measurements used in this study are presented in table 3.

The data analysis method used is descriptive statistics, the selection of the estimation model, the classical assumption test, the coefficient, the simultaneous hypothesis test, and the partial test. The multiple regression equation is used to determine how much influence intellectual capital has on the company's financial performance and market value.

\section{Model 1}

$\mathrm{YROE}=\alpha+\beta 1 \mathrm{XVACA}+\beta 2 \mathrm{XVAHU}+\beta 3 \mathrm{XSTVA}+\varepsilon$

\section{Model 2}

$\mathrm{YMtBV}=\alpha+\beta 1 \mathrm{XVACA}+\beta 2 \mathrm{XVAHU}+\beta 3 \mathrm{XSTVA}+$
Where:

YROE = financial performance

$\mathrm{YMtBV}=$ market value

$\alpha=$ constant

$\beta 1, \beta 2, \beta 3=$ regression coefficient

XVACA $=$ value added capital employed

XVAHU $=$ value added human capital

XSTVA = structural capital value added

\section{Results and Discussion}

The first step in this research is to conduct a descriptive statistical analysis using Eviews 9. The data results can be seen in table 4.

Table 4. shows that ROE has a maximum value of 0.412 for Fortune Mate Indonesia Tbk and a minimum value of -0.25 for Cowell Development Tbk. The mean value is 0.075 with a standard deviation value of 0.104 . $\mathrm{MtBV}$ gives a maximum value of 1798 to Alam Sutera Realty Tbk and a minimum value of 0.040 to Suryamas Dutamakmur Tbk. The mean value is 70.42 with a standard deviation of 232.5 .

The VACA variable has a maximum value of 4.451 for Metropolitan Land Ltd Tbk and a minimum value of 0.007 for Eureka Prima Jakarta Tbk. The mean value is 0.257 with a standard deviation value of 0.435 . The VAHU variable gives a maximum value of 261.9 for Pakuwon Jati Tbk and a minimum value of 0.779 for Bukit Darmo Property. The mean value is 9.720 with a standard deviation of 19.49. STVA variable shows a maximum value of 0.996 at Pakuwon Jati Tbk and a minimum value of -0.282 at Bukit Darmo Property. The mean value is 0.806 with a standard deviation of 0.153 .

Table 4. Descriptive Statistics Result

\begin{tabular}{|c|c|c|c|c|c|c|}
\hline & N & Mean & Median & Max & Min & Std. Dev \\
\hline ROE & 210 & 0.075 & 0.052 & 0.412 & -0.25 & 0.104 \\
\hline MtBV & 210 & 70.42 & 1.120 & 1798 & 0.040 & 232.5 \\
\hline VACA & 210 & 0.257 & 0.217 & 4.451 & 0.007 & 0.435 \\
\hline VAHU & 210 & 9.720 & 6.328 & 261.9 & 0.779 & 19.49 \\
\hline STVA & 210 & 0.806 & 0.842 & 0.996 & -0.28 & 0.153 \\
\hline
\end{tabular}


Furthermore, the researcher conducted a test to determine a good model in this study.

Table 5. Chow test result

\begin{tabular}{|c|c|c|}
\hline & Prob. Cross-section F & $\alpha$ \\
\hline Model 1 & 0.0000 & 0.05 \\
\hline Model 2 & 0.0000 & 0.05 \\
\hline
\end{tabular}

Table 5. shows the probability value of cross-section $\mathrm{F}$ less than 0.05. Thus, the suitable method is a fixed effect rather than a common effect.

Table 6. Hausman test result

\begin{tabular}{|c|c|c|}
\hline & Prob. Cross-section random & A \\
\hline Model 1 & 0.5491 & 0.05 \\
\hline Model 2 & 0.5931 & 0.05 \\
\hline
\end{tabular}

Table 6. shows the probability value of the random cross-section is more than 0.05 . So, the suitable method is a random effect rather than a fixed effect.

Table 7. Lagrange Multiplier test result

\begin{tabular}{|c|c|c|}
\hline & Prob. Cross-section breusch-pagan & A \\
\hline Model 1 & 0.0000 & 0.05 \\
\hline Model 2 & 0.0000 & 0.05 \\
\hline
\end{tabular}

Table 7. shows the probability value of the Breusch-pagan cross-section less than 0.05. Thus, the final test for selecting the right model for model 1 and model 2 is the random effect model.

In the next step, the classical assumption test is done. According to [39] and [40], when research has large data ( $\mathrm{n}>30$ ) it can be assumed that the data has been normally distributed. This study has a sample of 210 data, it can be concluded that the data has been normally distributed. The test results of this study are as follows:

Table 8. Multicollinearity test

\begin{tabular}{|l|l|l|l|}
\hline & VACA & VAHU & STVA \\
\hline VACA & 1 & 0.8045271157 & 0.263820466 \\
\hline VAHU & 0.8045271157 & 1 & 0.298451625 \\
\hline STVA & 0.2638204665 & 0.2984516256 & 1 \\
\hline
\end{tabular}

Table 8. shows the tolerance value for all variables $<0.9$, so that this research model does not occur multicollinearity.

Table 9. Glejser test result

\begin{tabular}{|c|c|c|c|}
\hline \multirow{2}{*}{$\alpha=0.05$} & \multicolumn{3}{|c|}{ Prob. Chi-square } \\
\cline { 2 - 4 } & VACA & VAHU & STVA \\
\hline Model 1 & 0.4832 & 0.5579 & 0.0513 \\
\hline Model 2 & 0.8197 & 0.9598 & 0.3211 \\
\hline
\end{tabular}

Table 9. shows the chi-square probability value in all models $>0.05$, which means that the model is free from heteroscedasticity.

Table 10. First Difference test result

\begin{tabular}{|c|c|}
\hline & Durbin-Watson \\
\hline Model 1 & 2.122593 \\
\hline Model 2 & 1.895254 \\
\hline
\end{tabular}

Table 10. shows the Durbin-Watson value for model 1 of 2.122583 and model 2 of 1.895254. The Durbin-Watson value is greater than $\mathrm{dU}=1.79326$ and less than 4-dU $=2.20674$. So, it can be interpreted that all variables are free from autocorrelation.

Table 11. Determination Coefficient Test Results

\begin{tabular}{|c|c|c|}
\hline & R-squared & Adjusted R-squared \\
\hline Model 1 & 0.073029 & 0.056072 \\
\hline Model 2 & 0.000883 & -0.017394 \\
\hline
\end{tabular}

Table 11 . shows the R-square value of $7.3 \%$ in model 1 and $0.08 \%$ in model 2 . This shows that only $7.3 \%$ of the financial performance (ROE) can be explained by the components of intellectual capital (VACA, VAHU, STVA), and the remaining $93.7 \%$ is explained by factors outside the model. And only $0.08 \%$ of the market value (MtBV) can be explained by the intellectual capital component (VACA, VAHU, STVA), and the remaining 99.92\% is explained by factors outside the model.

Table 12. F-Statistic test result

\begin{tabular}{|c|c|c|}
\hline$\alpha=0,05$ & F-statistic & Prob. (F-statistic) \\
\hline Model 1 & 4.306783 & 0.005923 \\
\hline Model 2 & 0.048291 & 0.985903 \\
\hline
\end{tabular}

Table 12. shows that model 1 has a prob. F-statistic value of $0.005923<0.05$, which means that all components of intellectual capital (VACA, VAHU, STVA) have a simultaneous significant effect on financial performance (ROE). Meanwhile, model 2 has a prob. F-statistical value of $0.985803>0.05$, which means that all components of intellectual capital (VACA, VAHU, STVA) have no significant effect on market value (MtBV).

Table 13. T-Statistic test result

\begin{tabular}{|c|c|c|c|}
\hline & & coefficient & Prob. \\
\hline \multirow{3}{*}{ Model 1 } & VACA & -0.017911 & 0.0940 \\
\cline { 2 - 4 } & VAHU & 0.000458 & 0.1363 \\
\cline { 2 - 4 } & STVA & 0.231222 & 0.0003 \\
\hline \multirow{3}{*}{ Model 2 } & VACA & -4.559510 & 0.4731 \\
\cline { 2 - 4 } & VAHU & 0.124020 & 0.4515 \\
\cline { 2 - 4 } & STVA & 10.94183 & 0.1096 \\
\hline
\end{tabular}

Table 13. shows in model 1 that the VACA variable on financial performance (ROE) has a probability of $0.940>$ 0.05 with a negative coefficient value. These results indicate that the VACA variable has a negative and 
insignificant effect on financial performance (ROE). This result is similar to the research conducted by [26] which states that capital employed has a negative and insignificant effect on the company's financial performance (ROE). This is different from research conducted by [28] that capital employed has a significant positive effect on financial performance (ROE). Based on the view of Resource-Based Theory, companies gain competitive advantage and financial performance by owning, controlling and utilizing important strategic assets. Capital employed describes how much value can be generated from the physical capital used. The result of this study is that capital employed has a negative and insignificant effect on the company's financial performance, meaning that capital employed does not affect the financial performance of property and real estate companies.

However, in model 2, the VACA variable on market value $(\mathrm{MtBV})$ has a probability of $0.4731>0.05$ with a negative coefficient value. These results indicate that the VACA variable has a negative and insignificant effect on market value (MtBV). The results of this study are similar to the research conducted by [38] which states that capital employed has a positive and insignificant effect on market value (MtBV). However, different research results are shown by [36] that capital employed has a significant positive effect on market value (MtBV). The view of Resource-Based Theory, according to [41], is that the determination of potential resources can create a continuous competitive advantage. The creation of these results is assisted by how the stakeholder relationship with the company. The better relationship will increase the perspective for investors so that the market value will increase. The results of this study indicate that capital employed has a negative and insignificant effect on the company's market value, meaning that if there is a decrease in the value of capital employed, it will not affect the company's market value.

In model 1, the VAHU variable on financial performance (ROE) has a probability of $0.1363>0.05$ with a positive coefficient value. These results indicate that the VAHU variable has a positive and insignificant effect on financial performance (ROE). This result is similar to the research conducted by [32] which states that human capital has no significant effect on financial performance (ROE). However, other studies have shown different results from previous studies, namely [21] stated that human capital has a significant effect on financial performance (ROE). Resource-Based Theory states that one of the potential resources for companies comes from human resources. These resources are in the form of providing training, expertise and skills to employees in supporting company development. Based on statistical results, human capital has a positive and insignificant effect on the company's financial performance, meaning that property and real estate companies are unable to maximize employee knowledge and skills for the company's progress, so that it will have an impact on the financial performance of property and real estate companies.

However, in model 2, the VAHU variable to market value (MtBV) has a probability of $0.4515>0.05$ with a positive coefficient value. These results indicate that the VAHU variable has a positive and insignificant effect on market value (MtBV). Similar results are shown in research conducted by [37] which states that human capital has a positive and insignificant effect on market value (MtBV). These results are different from research conducted by [12] that human capital has a significant positive effect on market value (MtBV). Human capital is the main resource of the Resource-Based Theory assumption because it is a source of innovation and anything that creates a positive market perception for the company in the eyes of the market. The ability of company employees greatly influences it as a competitive strategy. This study shows that human capital has a positive and insignificant effect on the market value of the company, meaning that if there is a decrease in human capital, it will not affect the company's market value.

The STVA variable on financial performance (ROE) has a probability of $0.003<0.05$ with a positive coefficient value in model 1 . These results explain that the STVA variable has a positive and significant effect on financial performance (ROE). This is because property \& real estate companies prioritize structural capital such as improving systems and operations on the tools used in running company operations. The results of this study are similar to research conducted by [19] which states that structural capital has a significant positive effect on company financial performance (ROE). This result is different from research conducted by [35] which states that structural capital has no effect on financial performance (ROE). According to Resource-Based Theory, structural capital is one of the strategies for creating company value, in the form of corporate culture, company operational systems, and others. The better the management of structural capital carried out by the company, the higher the results the company will get. This study shows that structural capital has a significant positive effect on the company's financial performance, meaning that the good management of the operational system and the application of organizational culture in property and real estate companies can improve the company's financial performance.

Meanwhile, the STVA variable on market value (MtBV) has a probability of $0.1096>0.05$ in model 2 . These results explain that the STVA variable has a positive and insignificant effect on market value (MtBV). Similar research results are shown in research conducted by [20] which states that structural capital has a positive and insignificant effect on market value (MtBV). This result is 
different from the research conducted by [27] which states that structural capital has a significant positive effect on market value (MtBV). The Resource-Based Theory view that structural capital resources are able to create added value for the company through the manufacturing process and all forms of intellectual property owned by the company, which triggers an increase in company value in the eyes of stakeholders. According to [42] some examples of intellectual property rights are patents, copyrighted software and trademarks. Based on the statistical results, it shows that structural capital has a positive and insignificant effect on the company's market value, meaning that the level of structural capital value of a company does not affect the company's market value.

\section{Conclusions}

This study aims to examine the effect of intellectual capital on the financial performance and market value of the property and real estate companies for the period 2014-2018. Based on the research results, it can be concluded that the value-added generated through capital employed (VACA) and human capital (VAHU) has no effect on financial performance (ROE). This shows that the value of VACA and VAHU does not affect financial performance (ROE). Also, the value-added generated through structural capital (STVA) has an effect on financial performance (ROE). This shows that the high and low value of STVA affects financial performance (ROE). Meanwhile, value-added generated through capital employed (VACA), human capital (VAHU), and structural capital (STVA) has no effect on market value (MtBV). This shows that the value of VACA, VAHU, STVA does not affect the market value (MtBV). The recommendation of this research is that the company management can maximize the management of its resources effectively and efficiently. Company managers pay more attention to resource management not only on structural capital, but also on capital employed and human capital in order to create higher added value so as to form a good market value to reflect an increase in the company's financial performance. In addition, investors should consider more when investing, to be more careful in looking at the intellectual capital owned by the company because of the important role of the company's intellectual capital as a reflection of good market value and the level of competitive financial performance. This study has limitations, namely, the results show that the level of influence of intellectual capital on financial performance and market value is low. Therefore, further research can add other variables such as corporate social responsibility or good corporate governance.

\section{REFERENCES}

[1] N. Ratri and Palupiningdyah, "The Influence of Motivation and Work Environment on Employee Performance of Banjarnegara Islamic Hospital,” Manag. Anal. J., vol. 3, no. 1, pp. 1-11, 2014.

[2] A. Arizqi, "Performance Enhancement Model of Human Resources through Knowledge Sharing,” J. Din. Manaj., vol. 8, no. 1, pp. 134-142, 2017.

[3] S. Martono, M. Khoiruddin, and N. A. Wulansari, "Remuneration Reward Management System As a Driven Factor of Employee Performance,” Int. J. Bus. Soc., vol. 19, no. S4, pp. 535-545, 2018.

[4] C. Agustina and A. Ardiansari, "The Influence of Macroeconomic Factors and Financial Performance on Firm Value,” Manag. Anal. J., vol. 4, no. 1, pp. 10-21, 2015.

[5] A. Rodoni and H. Ali, Modern Financial Management, Mitra Wacana Media, Jakarta, Indonesia, 2014.

[6] W. L. Andika and R. S. Witiastuti, “Analysis of Economic Value Added and Market Value Added as a Measure of Company Performance and Its Effect on Stock Prices,” Manag. Anal. J., vol. 6, no. 3, pp. 246-253, 2017.

[7] S. Nimtrakoon, "The Relationship between Intellectual Capital, Firms’ Market Value and Financial Performance: Empirical Evidence from ASIAN Countries,” J. Intellect. Cap., vol. 16, no. 3, pp. 587-618, 2014.

[8] S. Abied Luthfi, "The Effect of Earning Per Share, Price Earning Ratio, Return on Assets, Debt To Equity Ratio and Market Value Added on Stock Prices in the Jakarta Islamic Index Group," Manag. Anal. J., vol. 2, no. 2, pp. 1-8, 2013.

[9] I. Khajar, “The Influence of Right Issue on Company Financial Performance,” J. Din. Manaj., vol. 1, no. 1, pp. 27-33, 2013.

[10] I. Maftukhah, "Managerial Ownership, Institutional Ownership, and Financial Performance as Determinants of Company Capital Structure,” J. Din. Manaj., vol. 4, no. 1, pp. 69-81, 2013.

[11] L. J. Gitman, R. Juchau, and J. Flanagan, Principles of Managerial Finance, Pearson Higher Education, AU, 2015.

[12] A. Suhasti and K. Sudarma, "The Role of Mediation in Increasing Intellectual Capital Based Innovative Behavior,” Manag. Anal. J., vol. 8, no. 4, pp. 425-433, 2019.

[13] I.M. Adnyana, Hasanudin, A. Nurwulandari, "Empirical examination of intersectoral linkages between tourism and regional economy by using the social accounting matrix," Int. J. Econ. Bus. Adm, vol. 8, no. 1, pp. 425-432, 2020.

[14] S. Sarjana, N. Khayati, L. Warini, and P. Praswiyati, "Strengthening of Intellectual Capital Dimension," J. Din. Manaj., vol. 8, no. 2, pp. 216-232, 2017.

[15] A. Yuniawan, V. W. Putri, and Udin, "Developing An Alternative Model for The Relationship Among Social Capital, Adaptive-Integrative Leadership, Competitive Advantage, and Organizational Effectiveness,” Int. J. Civ. Eng. Technol., vol. 8, no. 11, pp. 52-60, 2017. 
[16] I. M. D. Ulum, Intellectual Capital: Concept and Empirical Study, Graha Ilmu, Yogyakarta, Indonesia, 2009.

[17] A. Public, Measuring the performance of intellectual capital in knowledge economy. 1998.

[18] Y. Y. Kor and J. T. Mahoney, “Edith Penrose’s (1959) Contributions to the Resource-based View of Strategic Management,” J. Manag. Stud., vol. 41, no. 1, pp. 183-191, 2004.

[19] Hasanudin, A. Nurwulandari, I.M. Adnyana, N. Loviana, "The effect of ownership and financial performance on firvalue of oil and gas mining companies in Indonesia," Int. J. Energy Econ. Policy, vol. 10, no. 5, pp. 103-109, 2020.

[20] L. F. Yulandari and H. Gunawan, "The Influence of Intellectual Capital on Market Value and Financial Performance of Companies Listed on the Indonesia Stock Exchange ” J. Appl. Manag. Account., vol. 3, no. 1, pp. 3650, 2019.

[21] D. Maditinos, D. Chatzoudes, C. Tsairidis, and G. Theriou, "The impact of intellectual capital on firms' market value and financial performance,” J. Intellect. Cap., vol. 12, no. 1, pp. 132-151, 2011.

[22] Q. A. S. Aritonang, H. Muharam, and S. Sugiono, "The Influence of Intellectual Capital on Financial Performance," J. Bisnis Strateg., vol. 25, no. 1, pp. 49-64, 2016.

[23] M. C. Chen, S. J. Cheng, and Y. Hwang, “An empirical investigation of the relationship between intellectual capital and firms' market value and financial performance," $J$. Intellect. Cap., vol. 6, no. 2, pp. 159-176, 2005.

[24] A. D. Pangestu and R. E. Wijaya, "Pengaruh Intellectual Capital Terhadap Market Value dan Kinerja Keuangan,” J. Akunt. Investasi, vol. 15, no. 2, pp. 90-100, 2014.

[25] S. Firer and S. Mitchell Williams, "Intellectual capital and traditional measures of corporate performance,” J. Intellect. Cap., vol. 4, no. 3, pp. 348-360, 2003.

[26] M. Haryanto and Henny, "The Influence of Intellectual Capital on the Company's Financial Performance and Market Value,” J. Manaj. Maranatha, vol. 12, no. 2, pp. 133-148, 2013.

[27] T. M. Oktavia, “The Influence of Intellectual Capital on Financial Performance and Market Value of Financial Sector Companies in Indonesia,” Diponegoro J. Account., vol. 4, no. 2, pp. 306-319, 2015.

[28] S. Rini and S. Boedi, "The Influence of Intellectual Capital on Banking Financial Performance,” Manaj. dan Akunt., vol. 17, no. 1, pp. 77-86, 2016.

[29] Subkhan and dyah pitaloka Citraningrum, “The Influence of IC on the Financial Performance of Banking Companies for the Period of 2005-2007,” J. Din. Akunt., vol. 2, no. 1, pp.
30-36, 2010.

[30] H. Harianja and S. Fauzie, "Value Added Analysis as an Indicator of Intellectual Capital on Banking Performance in Indonesia,” J. Ekon. dan Keuang., vol. 2, no. 5, pp. 265-281, 2014.

[31] K. H. Chan, "Impact of intellectual capital on organisational performance,” Learn. Organ., vol. 16, no. 1, pp. 22-39, 2009.

[32] N. Wijaya, “The Influence of Intellectual Capital on Financial Performance and Market Value of Banking Companies with the Value Added Intellectual Coefficient Method,” J. Bisnis dan Akunt., vol. 14, no. 3, pp. 157-180, 2012.

[33] Y. Firmansyah and Iswajuni, "The Influence of Intellectual Capital on Profitability, Market Value, Growth, and Actual Return in Companies Listed on the Indonesia Stock Exchange,” J. Ekon. Dan Bisinis, vol. 1, no. 1, pp. 50-59, 2014.

[34] N. Baroroh, “Analysis of the Effect of Intellectual Capital on the Financial Performance of Manufacturing Companies in Indonesia,” J. Din. Akunt., vol. 5, no. 2, pp. 172-182, 2013.

[35] F. Sardo and Z. Serrasqueiro, “A European empirical study of the relationship between firms' intellectual capital, financial performance and market value,” J. Intellect. Cap., vol. 18, no. 4, pp. 771-788, 2017.

[36] A. Yusuf and Gasim, “The Relevance of Intellectual Capital Value" J. Akunt. Multiparadigma, vol. 6, no. 2, pp. 201-213, 2015.

[37] I. Christiana and Nurwani, "The Influence of Intellectual Capital on Market Value,” J. Chem. Inf. Model., vol. 1, no. 4, pp. 50-55, 2019.

[38] A. Nurwulandari, I.M. Adnyana, Hasanudin, “Did inter-regional trade agreements bring mutual benefits? An empirical scheme of Indonesian commodity exports in Asean-China Free Trade Area,” Int. J. Financial Res., vol. 10, no. 6, pp. 241-249, 2019.

[39] W. W. Winarno, Econometric and Statistical Analysis with Eviews, UPP STIM YKPN, Yogyakarta, Indonesia, 2015.

[40] A. T. Basuki and N. Prawoto, "Regression Analysis in Economics \& Business Research,” pp. 1-239, 2015.

[41] L. Susanto, “Intellectual Capital and Firm Performance,” Int. J. Econ. Perspect., vol. 11, no. 1, pp. 1621-1631, 2017.

[42] W. V. Rapp, “International Processing INC. A Constructed Mini-case Reflecting Transnational Tax Issues Involving Intellectual Property," Universal Journal of Accounting and Finance, vol.6, no.4, pp. 123-131, 2018. DOI: 10.13189/ujaf.2018.060401. 